\title{
Pengembangan Perangkat Pembelajaran Matematika SMP Kelas VIII dengan Menggunakan Problem-Based Learning
}

\author{
Maria Trisna Sero Wondo \\ Program Studi Pendidikan Matematika, Universitas Flores Ende, Jalan Sam Ratulangi No. 10, Paupire, \\ Ende Tengah, Kabupaten Ende, Nusa Tenggara Timur, Indonesia \\ Email: trisnawondo@gmail.com
}

Received: 20 May 2017; Revised:7 June 2017; Accepted: 10 June 2017

\begin{abstract}
Abstrak
Penelitian ini bertujuan untuk menghasilkan perangkat pembelajaran matematika SMP kelas VIII semester genap dengan model problem-based learning berorientasi pada prestasi belajar, kemampuan pemecahan masalah, dan sikap percaya diri siswa. Jenis penelitian ini adalah penelitian pengembangan model Plomp (penelitian awal, pengembangan, penilaian). Subjek penelitian ini adalah guru dan siswa kelas VIII SMP Swasta Katolik Maria Goretti Ende. Analisis data dilakukan dengan mengkonversi data kuantitatif berupa skor hasil penilaian menjadi data kualitatif berupa nilai standar skala lima. Penelitian ini menghasilkan perangkat pembelajaran matematika kelas VIII semester genap berupa RPP dan LKS. Dari hasil validasi ahli, skor penilaian guru, penilaian siswa, observasi keterlaksanaan kegiatan pembelajaran, tes prestasi belajar, tes kemampuan pemecahan masalah, dan angket sikap percaya diri menunjukkan bahwa RPP dan LKS adalah valid, praktis, dan efektif.
\end{abstract}

Kata Kunci: Perangkat pembelajaran, problem-based learning, prestasi belajar, pemecahan masalah, percaya diri

\section{Developing Mathematics Learning Kits for $8^{\text {th }}$ Grade Using the Problem-Based Learning}

\begin{abstract}
This study aimed to produce mathematics learning kits using the problem based learning model oriented to the learning achievement, problem solving skill, and self-confidence for Grade VIII students of the junior high school (JHS) in the even semester. This study was and development study used the development model by Plomp (preliminary study, development, evaluation). The research subjects were teachers and students of Grade VIII of Swasta Katolik Maria Goretti Ende. The analysis of the data was done by converting the quantitative data in the form scores as the results of the evaluation into qualitative data in the form of five-scale standard scores. This study produce mathematics learning kits in the form of lesson plans and student worksheets for Grade VIII students of the junior high school in the even semester. The results of expert validation, teacher evaluation scores, students evaluation scores, an observation for the implementation of learning activities, learning achievement test, problem solving skill test, and self-confidence questionnaire show that lesson plans and student worksheets was valid, practical, and effective.
\end{abstract}

Keywords: learning kits, problem-based learning, learning achievement, problem solving, selfconfidence

How to Cite: Wondo, M. (2017). Pengembangan perangkat pembelajaran matematika SMP kelas VIII semester genap dengan model problem-based learning. PYTHAGORAS: Jurnal Pendidikan Matematika, 12(1), 76-86. doi:http://dx.doi.org/10.21831/pg.v12i1.14056

Permalink/DOI: http://dx.doi.org/10.21831/pg.v12i1.14056 


\section{PENDAHULUAN}

Pembelajaran matematika memiliki peran penting dalam menghadapi kemajuan IPTEK melalui penanaman berbagai keterampilan yang melibatkan kemampuan pemecahan masalah, berpikir kritis, logis, kreatif, dan bekerjasama. Berdasarkan Undang-Undang Nomor 20 Tahun 2003 tentang Sistem Pendidikan Nasional dapat diketahui bahwa potensi peserta didik yang perlu ditingkatkan dalam pembelajaran matematika meliputi aspek kognitif, afektif, dan psikomotor (Republik Indonesia, 2003). Terkait dengan pembelajaran, dalam Permendikbud Nomor 65 Tahun 2013 tentang Standar Proses Pendidikan Dasar dan Menengah, dijelaskan bahwa setiap satuan pendidikan harus melakukan perencanaan pembelajaran, pelaksanaan proses pembelajaran, serta penilaian proses pembelajaran untuk meningkatkan efisiensi dan efektivitas ketercapaian kompetensi lulusan (Mendikbud, 2013). Selain itu, perencanaan pembelajaran dirancang dalam bentuk silabus dan Rencana Pelaksanaan Pembelajaran (RPP) yang mengacu pada Standar Isi. Perencanaan pembelajaran meliputi penyusunan rencana pelaksanaan pembelajaran dan penyiapan media dan sumber belajar, perangkat penilaian pembelajaran, dan skenario pembelajaran. Rencana pelaksanaan pembelajaran (RPP) merupakan panduan langkah-langkah yang dilakukan oleh guru dalam kegiatan pembelajaran yang disusun dalam skenario kegiatan (Trianto, 2012, p.108).

Selain RPP, guru juga memerlukan suatu media untuk memudahkan siswa dalam belajar secara mandiri. Salah satu media yang biasa digunakan untuk membantu siswa dalam belajar adalah Lembar Kegiatan Siswa (LKS) yang tentu harus dirancang agar sejalan dengan RPP. Hal ini sesuai dengan pendapat beberapa ahli yang antara lain mengatakan bahwa LKS dibuat/digunakan oleh guru sebagai penunjang dalam mencapai tujuan pembelajaran (Brown, 2009, p.25). Selain itu, dengan menggunakan LKS, guru dapat mengorganisasikan kegiatan belajar siswa secara terarah (McArdle, 2010, p.169). Hal tersebut dikarenakan LKS memuat langkah-langkah atau petunjuk bagi siswa dalam menyelesaikan tugas-tugas yang diberikan (Depdiknas, 2008, p.13).

Dalam proses pembelajaran seorang guru harus mampu mengorganisir pembelajaran dengan baik sedemikian sehingga dapat memfasilitasi siswa untuk mencapai kompetensikompetensi yang telah ditentukan dalam standar isi kurikulum. Oleh karena itu, guru harus melakukan inovasi, perubahan maupun variasi dalam mengorganisir proses pembelajaran agar sesuai dengan tuntutan kurikulum (Ahmadi \& Amri, 2014, p.81). Dalam hal ini, guru harus mampu memilih model pembelajaran yang paling sesuai untuk membelajarkan siswa.

Salah satu model pembelajaran yang bisa digunakan guru dalam proses pembelajaran, adalah model pembelajaran problem-based learning (PBL). Problem-based learning merupakan salah satu model pembelajaran yang direkomendasikan untuk digunakan khususnya dalam implementasi kurikulum yang digunakan saat ini, yakni kurikulum 2013 (Retnawati, 2015). Terdapat beberapa alasan mengapa PBL direkomendasikan dalam implementasi K13, antara lain sebagai berikut. PBL memberikan penekanan pada proses pemecahan masalah berkaitan dengan kehidupan sehari-hari yang kompleks dan tidak terstruktur (Santrock, 2011, p.320; Ajai \& Imoko, 2015, p.47). PBL juga merupakan pembelajaran yang mampu memberikan peluang kepada siswa untuk aktif dalam pembelajaran (Arends \& Kilcher, 2010, p.328; Eric, 2010, p.1). Tujuan atau goal diharapkan adalah siswa menjadi pemikir yang fleksibel dan pemecah masalah (Ertmer \& Simons, 2006, p.51), berpikir kritis, kreatif, dan memonitor pemahaman mereka (Sungur \& Tekkaya, 2006, p.308) serta menghasilkan siswa yang memiliki kemampuan berpikir tingkat tinggi (Sumarmo \& Nishitani, 2010, pp.10-12; Sastrawati, Rusdi, \& Syamsurizal, 2011, p.13; Magsino, 2014, p.1).

Salah satu proses penting dalam PBL adalah pemecahan masalah yang melibatkan berbagai potensi yang dimiliki siswa selama proses tersebut. Pemecahan masalah merupakan cara atau metode yang oleh seseorang menggunakan pengetahuan, keterampilan, dan pemahaman yang diperoleh sebelumnya untuk menghadapi situasi lainnya (Krulik \& Rudnick, 1995, p.4). Pemecahan masalah adalah hal yang sangat penting karena pemecahan masalah merupakan sarana mempelajari ide matematika dan keterampilan matematika (NCTM, 2000, p.182), mengembangkan kemampuan berpikir, dan keterampilan dasar (Pimta \& Nuangchalem, 2009, p.381). Proses pemecahan masalah melibatkan berbagai proses antara lain menganalisis, menafsirkan, penalaran, memprediksi, mengevaluasi dan merefleksikan (Karatas \& Baki, 2013, p.249), melakukan penalaran untuk menutup kesenjangan antara kenyataan yang terjadi 
dan apa yang diharapkan Haylock \& Thangata (2007, pp.145-146).

Karakteristik PBL sebagaimana uraian di atas, sesuai dengan standar isi yang ditetapkan dalam implementasi kurikulum 2013. Hal tersebut menunjukkan bahwa implementasi PBL dalam proses pembelajaran tidak hanya meningkatkan prestasi belajar siswa secara khusus pada materi tertentu, tetapi juga melatih siswa untuk mengembangkan kemampuan-kemampuan yang mereka butuhkan untuk memecahkan masalah yang mereka hadapi dalam kehidupan seharihari. Hal ini sesuai dengan konsep dari prestasi adalah "knowledge, skills, and abilities that students have developed as a result of instruction" (Nitko \& Brookhart, 2011, p.497) yang tercermin dari nilai, tingkatan, dan bentuk lain yang menjadi bukti pencapaian siswa (Collins \& O’Brien, 2003, p.4).

Selain itu, PBL yang dilaksanakan dengan menggunakan konsep belajar dalam berkelompok dan kegiatan presentasi memungkinkan terjadinya kolaborasi antar siswa. Aktivitas dalam PBL dapat mengembangkan rasa percaya diri siswa (Farhan \& Retnawati, 2014; Abdullah, \& Yunita, 2011), sehingga memudahkan siswa dalam menyampaikan ide-ide mereka sekaligus argumen yang mereka gunakan. Kepercayaan diri merupakan faktor yang sangat penting dalam kesuksesan seseorang dalam menyelesaikan masalah (Azmandian, 2010, p.145) karena berkaitan berkaitan dengan keyakinan akan kemampuan diri (Cretchley, 2008, p.152), dan harga diri seorang siswa (Goel \& Aggarwal, 2012, p.89). Kepercayaan diri siswa sangat berpengaruh positif terhadap prestasi belajar siswa (Hamdan, 2009, p.14; Hannula, Maijala, \& Pehkonen, 2004, p.23).

Berdasarkan uraian di atas, implementasi PBL merupakan sesuatu yang sangat penting untuk dilakukan oleh guru dalam pembelajaran matematika. Untuk melaksanakan PBL diperlukan perencanaan yang matang, mulai dari penyusunan rencana pelaksanaan pembelajaran (RPP), maupun penyediaan sumber-sumber dan media pembelajaran yang dapat membantu siswa selama proses pembelajaran berlangsung. Salah satu media sekaligus sumber belajar yang dapat dikembangkan adalah lembar kegiatan siswa (LKS). Oleh karena itu, penelitian ini bertujuan untuk menghasilkan perangkat pembelajaran matematika SMP kelas VIII semester genap dengan menggunakan problem-based learning berorientasi pada prestasi belajar, kemampuan pemecahan masalah, dan sikap percaya diri siswa yang layak digunakan.

\section{METODE}

Jenis penelitian ini adalah penelitian pengembangan yang bertujuan menghasilkan produk berupa perangkat pembelajaran dan menguji kualitasnya. Model pengembangan yang digunakan dalam penelitian ini diadopsi dari model pengembangan Plomp yang terdiri atas tiga tahapan yaitu preliminary research phase (fase penelitian awal), development or prototyping phase (fase pengembangan), dan assesment phase (fase penilaian).

Penelitian ini dilaksanakan di SMP Swasta Katolik Maria Goretti Ende dari bulan Maret sampai dengan bulan April 2016.

Subjek uji coba terbatas pada penelitian pengembangan ini adalah 9 siswa kelas VIII B SMP Swasta Katolik Maria Goretti Ende. Sembilan siswa tersebut terdiri atas tiga siswa berkemampuan tinggi, tiga siswa berkemampuan sedang, dan tiga siswa berkemampuan rendah. Sementara untuk subjek uji coba lapangan melibatkan siswa kelas VIII A SMP Swasta Katolik Maria Goretti Ende yang terdiri atas 40 siswa dan 1 orang guru. Penelitian ini dilaksanakan pada semester genap tahun pelajaran 2015/2016.

\section{Prosedur Pengembangan}

Prosedur pengembangan yang dilakukan meliputi preliminary research phase, development or prototyping phase, dan assesment phase. Preliminary research phase (fase penelitian awal) merupakan fase pertama atau fase persiapan untuk pengembangan produk. Fase ini bertujuan untuk mengumpulkan informasi melalui tinjauan pustaka mengenai konsep dan teori yang berkaitan dengan pengembangan perangkat pembelajaran dengan model problem based learning berorientasi pada prestasi belajar, kemampuan pemecahan masalah dan sikap percaya diri siswa. Selain itu juga dilakukan pengumpulan informasi tentang permasalahan yang terjadi di lapangan. Pada fase ini dilakukan identifikasi dan kajian terhadap kondisi siswa, pembelajaran matematika yang berlangsung di sekolah, kompetensi yang harus dicapai siswa, dan materi matematika kelas VIII semester genap. Development or prototyping phase (fase pengembangan) merupakan fase kedua dalam proses pengembangan produk. Pada fase ini dilakukan kegiatankegiatan: (1) merancang dan menyusun Rencana 
Pelaksanaan Pembelajaran (RPP) dan (2) merancang dan menyusun Lembar Kegiatan Siswa (LKS). Hasil dari fase ini adalah draft 1 perangkat pembelajaran matematika dengan model problem based learning. RPP yang dikembangkan memuat langkah-langkah sistematis pembelajaran yang di dalamnya memuat tahapan problem based learning. Adapun LKS yang dikembangkan memuat aktivitas siswa berdasarkan tahapan model problem based learning yang berorientasi pada prestasi belajar, kemampuan pemecahan masalah, dan sikap percaya diri siswa.

Tahap akhir adalah Assesment phase (fase penilaian) yang dilakukan tiga kegiatan utama. Pertama, kegiatan validasi. Kegiatan ini dilakukan untuk menguji validitas isi rancangan awal perangkat pembelajaran (draft 1). Uji validitas isi ini dilakukan oleh ahli (ahli pembelajaran matematika) untuk menilai dan memberikan masukan terhadap produk awal perangkat pembelajaran sebelum diujicobakan. Hasil dari validasi ahli direvisi sesuai dengan saran yang diberikan oleh validator sehingga kriteria kevalidan perangkat pembelajaran dapat terpenuhi. Hasil dari revisi yang telah memenuhi kriteria kevalidan ini selanjutnya disebut draft 2 . Kedua, uji coba terbatas. Perangkat pembelajaran yang sudah valid (draft 2), akan dilakukan uji coba terbatas pada guru dan siswa dalam skala kecil. Pada tahapan uji coba ini terdiri atas dua, yaitu penilaian siswa (uji keterbacaan) dan penilaian dari guru terhadap perangkat pembelajaran yang dikembangkan. Uji coba atau penilaian siswa hanya terbatas pada LKS dan pelaksanaan pembelajaran yang bertujuan untuk mengetahui kemudahan/keterbacaan dalam penggunaan produk perangkat pembelajaran yang dikembangkan. Siswa yang memberikan penilaian terdiri atas siswa dengan kemampuan tinggi, sedang dan rendah. Hasil dari uji coba terbatas dianalisis dan direvisi sesuai hasil penilaian siswa (uji keterbacaan) dan penilaian guru. Hasil penilaian siswa dan saran dari guru dijadikan acuan dalam merevisi produk agar memenuhi kriteria praktis. Hasil revisi produk ini selanjutnya disebut draft 3. Ketiga, uji coba lapangan. Perangkat pembelajaran yang sudah valid (draft 3), akan dilakukan uji coba lapangan dengan skala besar. Uji coba lapangan dilakukan dengan menerapkan/ menggunakan produk yang sudah dikembangkan, yaitu RPP dan LKS dalam pembelajaran matematika oleh guru. Selanjutnya diberikan tes hasil belajar berupa tes prestasi belajar untuk mengukur prestasi belajar siswa, tes kemampuan pemecahan masalah untuk mengukur kemampuan pemecahan masalah siswa serta memberikan angket kepercayaan diri untuk mengetahui sikap percaya diri siswa terhadap matematika dan pembelajarannya. Uji coba lapangan bertujuan untuk memperoleh data keefektifan perangkat pembelajaran matematika yang dkembangkan yang berorientasi pada prestasi belajar, kemampuan pemecahan masalah dan sikap percaya diri siswa.

Setelah uji coba dilakukan, hasil dari proses tersebut dianalisis untuk mengetahui apakah perangkat yang dikembangkan telah mencapai kriteria efektif dan praktis. Produk perangkat pembelajaran matematika tersebut yang telah diujicobakan dilakukan revisi berdasarkan saran dari guru yang menggunakan perangkat. Hasil revisi tersebut merupakan produk akhir (draft 4) dari perangkat pembelajaran matematika yang dikembangkan.

\section{Data, Instrumen, dan Teknik Pengumpulan Data}

Data penelitian ini berbentuk kualitatif dan kuantitatif. Data kualitatif diperoleh dari saran/masukan yang diperoleh dari validator, guru dan siswa saat menilai keterbacaan perangkat. Data kuantitatif diperoleh dari skor penilaian validator terhadap perangkat, penilaian guru, penilaian siswa, lembar observasi keterlaksanaan kegiatan pembelajaran, skor tes prestasi belajar, skor tes kemampuan pemecahan masalah, dan skor angket sikap percaya diri.

Instrumen yang digunakan dalam penelitian ini meliputi: (1) instrumen untuk mengukur kevalidan yang terdiri atas lembar validasi RPP, lembar validasi LKS, lembar validasi instrumen evaluasi berupa tes prestasi belajar, tes kemampuan pemecahan masalah, dan angket sikap percaya diri; (2) instrumen untuk mengukur kepraktisan yang terdiri atas lembar penilaian guru, lembar penilaian siswa, dan lembar observasi keterlaksanaan kegiatan pembelajaran; dan (3) instrumen untuk mengukur keefektifan berupa soal pretest dan posttest prestasi belajar, soal pretest dan posttest kemampuan pemecahan masalah, dan angket sikap percaya diri siswa.

\section{Teknik Analisis Data}

Data yang diperoleh dari proses pengumpulan data kemudian dianalisis dan diarahkan untuk menjawab tujuan penelitian yaitu menghasilkan perangkat pembelajaran matematika yang memenuhi kriteria valid, praktis, dan efektif. Data yang berupa skor validasi ahli, skor 
penilaian guru, skor penilaian siswa, dan skor angket sikap percaya diri yang diperoleh dalam bentuk skor skala lima dikonversikan menjadi data kualitatif, dengan acuan rumus yang diadaptasi dari Widoyoko (2009, p.238) sebagaimana ditunjukkan pada Tabel 1.

Tabel 1. Kriteria Konversi Data

\begin{tabular}{cc}
\hline Interval Skor & Kategori \\
\hline$X>\bar{X}_{i}+1,8 s b_{i}$ & Sangat baik \\
$\bar{X}_{i}+0,6 s b_{i}<X \leq \bar{X}_{i}$ & Baik \\
$+1,8 s b_{i}$ & \\
$\bar{X}_{i}-0,6 s b_{i}<X \leq \bar{X}_{i}$ & Cukup \\
$+0,6 s b_{i}$ & \\
$\bar{X}_{i}-1,8 s b_{i}<X \leq \bar{X}_{i}$ & Kurang \\
$-0,6 s b_{i}$ & \\
$X \leq \bar{X}_{i}-1,8 s b_{i}$ & Sangat kurang \\
\hline
\end{tabular}

Keterangan:

$X=$ skor empiris

$\bar{X}_{i}=\frac{1}{2}($ skor maksimum ideal + skor minimum ideal $)$

$s b_{i}=\frac{1}{6}$ (skor maksimum ideal - skor minimum ideal)

Kriteria kualitatif yang digunakan untuk menganalisis kevalidan perangkat adalah sangat valid, valid, cukup valid, kurang valid, dan tidak valid. Perangkat pembelajaran dikatakan valid jika kevalidan perangkat pembelajaran yang dicapai minimal dalam kategori valid.

Perangkat pembelajaran dikatakan praktis berdasarkan penilaian guru dan penilaian siswa jika kepraktisan perangkat pembelajaran yang dicapai minimal dalam kategori praktis. Perangkat pembelajaran dikatakan praktis ditinjau dari keterlaksanaan kegiatan pembelajaran jika persentase keterlaksanaan kegiatan pembelajaran guru dan persentase keterlaksanaan kegiatan pembelajaran siswa masing-masing memenuhi kategori praktis. Kriteria kualitatif yang digunakan untuk menganalisis kepraktisan adalah sangat praktis, praktis, cukup praktis, kurang praktis, dan tidak praktis.

Keefektifan dari perangkat pembelajaran yang dikembangkan ditinjau dari tiga aspek yaitu prestasi belajar, kemampuan pemecahan masalah, dan sikap percaya diri siswa. Perangkat pembelajaran dikatakan efektif ditinjau dari prestasi belajar jika: (a) terdapat peningkatan nilai rata-rata kelas berdasarkan hasil pretest dan posttest, (b) persentase banyaknya siswa dengan nilai tes prestasi belajar pada kelas uji coba yang memenuhi KKM adalah $\geq 80 \%$. Perangkat pembelajaran dikatakan efektif ditinjau dari kemampuan pemecahan masalah jika: (a) terdapat peningkatan nilai rata-rata kelas berdasarkan hasil pretest dan posttest, (b) persentase banyak- nya siswa dengan nilai tes kemampuan pemecahan masalah pada kelas uji coba yang memenuhi $\mathrm{KKM}$ adalah $\geq 80 \%$. Perangkat pembelajaran dikatakan efektif ditinjau dari sikap percaya diri jika: (a) persentase banyaknya siswa pada kelas uji coba memiliki sikap percaya diri dengan kategori minimal tinggi adalah $\geq$ $80 \%$, (b) persentase banyaknya siswa yang mengalami peningkatan sikap positif dari hasil sebelumnya pada kelas uji coba adalah $\geq 80 \%$.

\section{HASIL DAN PEMBAHASAN}

\section{Hasil Pengembangan}

Pengembangan perangkat pembelajaran ini di awali fase penelitian awal. Pada fase penelitian awal dilakukan identifikasi dan kajian. Fase ini merupakan tahap pra-perencanaan tentang produk berupa perangkat pembelajaran matematika dengan model problem based learning (PBL) yang berorientasi pada prestasi belajar, kemampuan pemecahan masalah, dan sikap percaya diri siswa. Pada fase ini peneliti mengidentifikasi produk yang sesuai dengan sasaran peserta didik, mengidentifikasi kondisi siswa, pembelajaran matematika yang berlangsung di sekolah, kurikulum 2013, kompetensi yang harus dicapai siswa, dan materi matematika kelas VIII semester genap.

Fase selanjutnya adalah fase pengembangan. Pada fase ini, dirancang dan disusun perangkat pembelajaran matematika berupa rencana pelaksanaan pembelajaran (RPP) yang mengacu pada langkah-langkah PBL dan lembar kegiatan siswa (LKS) yang dirancang dan disusun dengan karakteristik $P B L$. Hasil dari fase ini adalah draft 1 perangkat pembelajaran matematika dengan PBL.

Produk awal yang dikembangkan selanjutnya divalidasi kepada dua ahli untuk mengetahui kualitas kevalidan produk yang dikembangkan serta instrumen evaluasi yang digunakan dalam penelitian. Setelah proses validasi dilaksanakan dan produk pengembangan telah direvisi, maka selanjutnya dilakukan uji coba terbatas dan uji coba lapangan. Hasil pengembangan produk dideskripsikan sebagai berikut.

Perangkat pembelajaran yang dikembangkan terdiri atas rencana pelaksanaan pembelajaran (RPP) dan lembar kegiatan siswa (LKS) dengan model problem-based learning dan disesuaikan dengan pendekatan saintifik. Karakteristik dari perangkat pembelajaran yang dikembangkan antara lain: tujuan dan kegiatan pembelajaran mengarah kepada prestasi belajar, 
kemampuan pemecahan masalah, dan sikap percaya diri; menggunakan masalah nyata sebagai titik awal dalam pembelajaran yang bertujuan untuk mengkonstruksi pengetahuan siswa; masalah yang digunakan merupakan masalah nyata; memuat langkah problem-based learning dengan pendekatan saintifik.

Adapun tahapan kegiatan yang dilakukan dalam proses pembelajaran adalah sebagai berikut. Pertama penyajian masalah, yaitu tahap ketika siswa dihadapkan pada masalah-masalah dunia nyata yang merangsang rasa ingin tahu siswa dan memotivasi siswa untuk melakukan pemecahan msalah. Siswa mengamati masalah yang disajikan dan mengajukan pertanyaan terkait permasalahan yang disajikan. Kedua, perencanaan penyelesaian masalah. Pada tahap ini, siswa dalam kelompok kecil menyusun pertanyaan terhadap permasalahan yang diamati dan merancang langkah penyelesaian permasalahan dengan mengumpulkan informasi-informasi yang dibutuhkan melalui kegiatan pengamatan yang telah dilakukan. Siswa dibimbing untuk menyusun pertanyaan dan rencana penyelesaian terhadap permasalahan yang disajikan. Ketiga, penyelidikan masalah. Pada tahap ini, siswa dengan kelompoknya melakukan penyelidikan terhadap permasalahan yang disajikan melalui data-data atau informasi yang telah dikumpulkan. Pada tahap ini, siswa berdiskusi bersama teman sekelompok untuk menentukan solusi (mengasosiasi) dari permasalahan. Selain itu dengan kegiatan diskusi bersama dapat memantapkan pemahaman mereka terhadap permasalahan yang diselesaikan. Keempat, menyajikan hasil. Pada tahap penyajian hasil, siswa mengkomunikasikan hasil diskusi kelompoknya di depan kelas. Kelima, menganalisis dan mengevaluasi. Inti dari kegiatan ini adalah melakukan evaluasi atau tinjauan ulang terhadap hasil yang telah diperoleh. Melalui tahap ini, berbagai kesalahan dikoreksi secara bersamasama.

Rencana pelaksanaan pembelajaran (RPP) dan lembar kegiatan siswa (LKS) yang dikembangkan terdiri atas enam RPP dan enam LKS untuk materi SMP kelas VIII semester genap yaitu sistem persamaan linear dua variabel, persamaan kuadrat, lingkaran, perbandingan dan peluang. Karakteristik dari RPP yang dikembangkan yaitu RPP disusun berdasarkan kurikulum 2013, RPP disusun berdasarkan KD serta indikator pencapaiannya, kegiatan pembelajaran disusun berdasarkan tahapan PBL dengan pendekatan saintifik, pembelajaran mengguna- kan masalah nyata, RPP terintegrasi dengan lembar kegiatan siswa (LKS), adanya soal latihan untuk memfasilitasi siswa dalam mengembangkan prestasi belajar dan kemampuan pemecahan masalah, serta kegiatan pembelajarannya memfasilitasi siswa dalam mengembangkan pestasi belajar, kemampuan pemecahan masalah, dan kepercayaan diri siswa.

Karakteristik dari LKS yang dikembangkan yaitu masalah yang disajikan bertujuan untuk mengkonstruksi pengetahuan siswa, menggunakan masalah nyata, tahapan dalam LKS disusun secara sistematis berdasarkan tahapan model PBL dengan pendekatan saintifik, LKS disusun sebagai sarana untuk mengembangkan prestasi belajar, kemampuan pemecahan masalah, dan kepercayaan diri siswa, serta menggunakan petunjuk yang runtun agar mudah digunakan siswa. Perangkat pembelajaran yang dikembangkan ini dirancang untuk menumbuhkan kemampuan siswa dalam memecahkan masalah pada pembelajaran matematika, dapat mengatasi kesulitan belajar siswa, memberikan sikap percaya diri terhadap matematika dan pembelajarannya serta meningkatkan prestasi belajar siswa.

\section{Hasil Uji Coba Produk}

Hasil kegiatan uji coba perangkat menghasilkan data kevalidan, kepraktisan, dan keefektifan. Kevalidan perangkat pembelajaran dilakukan oleh dua dosen pendidikan matematika yang menilai perangkat pembelajaran. Adapun hasil penilaian validasi ahli oleh dua validator terhadap perangkat pembelajaran seperti pada Tabel 2.

Tabel 2. Skor Hasil Validasi Ahli terhadap Perangkat Pembelajaran

\begin{tabular}{|c|c|c|}
\hline \multirow{2}{*}{ Validator } & \multicolumn{2}{|c|}{ Total Skor } \\
\hline & RPP & LKS \\
\hline 1 & 160 & 95 \\
\hline 2 & 143 & 88 \\
\hline Skor tiap aspek & 151,5 & 91,5 \\
\hline Skor perangkat & \multicolumn{2}{|c|}{243} \\
\hline
\end{tabular}

Berdasarkan hasil validasi ahli dapat diketahui sejauh mana perangkat pembelajaran yang telah dibuat memenuhi kriteria valid. Data berupa skor penilaian dari ahli untuk perangkat pembelajaran dapat dilihat pada Tabel 3 .

Tabel 3. Analisis Validasi Perangkat Pembelajaran

\begin{tabular}{ccc}
\hline Komponen & Skor Empiris & Kategori \\
\hline RPP & 151,5 & Sangat Valid \\
\hline
\end{tabular}




\begin{tabular}{clc}
\hline LKS & 91,5 & \multicolumn{1}{c}{ Sangat Valid } \\
Total & $\mathbf{2 4 3}$ & \multicolumn{1}{c}{ Sangat Valid } \\
\hline Berdasarkan & penilaian kevalidan oleh \\
validator, perangkat pembelajaran dikatakan va- & perang \\
lid jika kevalidan perangkat pembelajaran yang \\
dicapai minimal dalam kategori valid. Demikian \\
juga untuk RPP dan LKS dikatakan valid jika \\
kevalidan yang dicapai masing-masing minimal \\
dalam kategori valid. Dengan hasil ini maka \\
perangkat pembelajaran dinyatakan valid dan \\
layak digunakan.
\end{tabular}

Kepraktisan perangkat pembelajaran diperoleh dari hasil penilaian guru, penilaian siswa, dan keterlaksanaan kegiatan pembelajaran. Adapun data hasil penilaian guru terhadap perangkat pembelajaran seperti pada Tabel 4.

Tabel 4. Data Hasil Penilaian Guru terhadap Perangkat Pembelajaran

\begin{tabular}{cccc}
\hline \multirow{2}{*}{ Penilai } & \multicolumn{3}{c}{ Skor Empiris } \\
\cline { 2 - 3 } & RPP & LKS \\
\hline Guru & 40 & 39 \\
Skor Perangkat & & \multicolumn{2}{c}{ 79 } \\
\hline
\end{tabular}

Berdasarkan data hasil penilaian guru, dapat dianalisis untuk mengetahui sejauh mana perangkat pembelajaran yang dibuat memenuhi kriteria praktis. Analisis data kepraktisan menurut penilaian guru untuk RPP dan LKS dapat dilihat pada Tabel 5 berikut.

Tabel 5. Analisis Kepraktisan Perangkat

Pembelajaran Berdasarkan Penilaian Guru

\begin{tabular}{ccc}
\hline $\begin{array}{c}\text { Perangkat } \\
\text { Pembelajaran }\end{array}$ & $\begin{array}{c}\text { Skor } \\
\text { Empiris }\end{array}$ & Kategori \\
\hline RPP & 40 & Sangat Praktis \\
LKS & 39 & Sangat Praktis \\
Total & $\mathbf{7 9}$ & Sangat Praktis \\
\hline
\end{tabular}

Berdasarkan penilaian guru, perangkat pembelajaran dikatakan praktis jika kepraktisan perangkat pembelajaran yang dicapai minimal dalam kategori praktis. Demikian juga RPP dan LKS dikatakan praktis jika kepraktisan yang dicapai masing-masing minimal dalam kategori praktis. Dengan hasil ini maka perangkat pembelajaran dinyatakan praktis menurut penilaian guru.

Tabel 6. Data Hasil Penilaian Siswa terhadap Perangkat Pembelajaran

\begin{tabular}{ccc}
\hline \multirow{2}{*}{ Penilai } & \multicolumn{2}{c}{ Skor Total } \\
\cline { 2 - 3 } & Pembelajaran & LKS \\
\hline Siswa & 151 & 160 \\
Skor tiap aspek & 16,8 & 17,8 \\
Skor perangkat & \multicolumn{2}{c}{$\mathbf{3 4 , 6}$} \\
\hline
\end{tabular}

Selain kepraktisan guru, siswa juga mempunyai andil dalam menentukan kepraktisan perangkat pembelajaran melalui lembar penilaian siswa. Adapun data hasil penilaian siswa terhadap perangkat pembelajaran seperti pada Tabel 6. Berdasarkan data hasil penilaian siswa, dapat dianalisis untuk mengetahui sejauh mana perangkat pembelajaran yang dibuat memenuhi kriteria praktis. Analisis data kepraktisan menurut penilaian siswa untuk pembelajaran dan pemanfaatan LKS dapat dilihat pada Tabel 7.

Tabel 7. Analisis Kepraktisan Perangkat Pembelajaran Berdasarkan Penilaian Siswa

\begin{tabular}{lccc}
\hline $\begin{array}{c}\text { Aspek } \\
\text { Penilaian }\end{array}$ & $\begin{array}{c}\text { Skor } \\
\text { Total }\end{array}$ & $\begin{array}{c}\text { Skor } \\
\text { Empiris }\end{array}$ & Kategori \\
\hline Pembelajaran & 151 & 16,8 & Praktis \\
Pemanfaatan & 160 & 17,8 & Sangat Praktis \\
LKS & $\mathbf{3 1 1}$ & $\mathbf{3 4 , 6}$ & Sangat Praktis \\
Total &
\end{tabular}

Berdasarkan penilaian siswa, perangkat pembelajaran dikatakan praktis jika kepraktisan perangkat pembelajaran yang dicapai minimal dalam kategori praktis. Demikian juga untuk pembelajaran dan pemanfaatan LKS dikatakan praktis jika kepraktisan yang dicapai masingmasing minimal dalam kategori praktis. Dengan hasil ini maka perangkat pembelajaran dinyatakan praktis menurut penilaian siswa.

Kepraktisan dari hasil observasi keterlaksanaan pembelajaran dipenuhi jika persentase keterlaksanaan kegiatan pembelajaran guru dan persentase keterlaksanaan kegiatan pembelajaran siswa masing-masing memenuhi kategori praktis. Tabel 8 menunjukkan data hasil observasi keterlaksanaan pembelajaran.

Tabel 8. Data Hasil Observasi Keterlaksanaan Pembelajaran

\begin{tabular}{ccc}
\hline \multirow{2}{*}{ Pertemuan } & \multicolumn{2}{c}{ Keterlaksanaan } \\
\cline { 2 - 3 } & Kegiatan Guru & Kegiatan Siswa \\
\hline I & $83 \%$ & $78 \%$ \\
II & $94 \%$ & $89 \%$ \\
III & $100 \%$ & $100 \%$ \\
IV & $94 \%$ & $94 \%$ \\
V & $100 \%$ & $100 \%$ \\
VI & $100 \%$ & $100 \%$ \\
Rata-rata & $\mathbf{9 5 , 4 \%}$ & $\mathbf{9 4 \%}$ \\
Kategori & Sangat Praktis & Sangat Praktis \\
\hline
\end{tabular}

Berdasarkan data hasil observasi keterlaksanaan pembelajaran, dapat dianalisis untuk mengetahui sejauh mana perangkat pembelajaran yang dibuat memenuhi kriteria praktis. Hasil analisis kepraktisan perangkat pembelajaran berdasarkan observasi keterlaksanaan kegiatan pembelajaran disimpulkan bahwa perangkat 
pembelajaran yang dikembangkan memenuhi kategori praktis berdasarkan persentase keterlaksanaan kegiatan pembelajaran. Dari hasil penilaian guru, penilaian siswa, dan observasi keterlaksanaan kegiatan pembelajaran diperoleh bahwa perangkat yang dikembangkan praktis.

Tabel 9. Nilai Rata-rata dan Persentase

Ketuntasan Belajar Berdasarkan TPB

\begin{tabular}{ccccc}
\hline \multirow{2}{*}{$\begin{array}{c}\text { Jumlah } \\
\text { Siswa }\end{array}$} & \multicolumn{2}{c}{ Nilai Rata-rata } & \multicolumn{2}{c}{ Ketuntasan } \\
\cline { 2 - 5 } & Pretest & Posttest & Pretest & Posttest \\
\hline 40 & 36,6 & 82,6 & $(0 \%)$ & $(97,5 \%)$ \\
\hline
\end{tabular}

Keefektifan perangkat pembelajaran diperoleh dengan menganalisis data hasil tes prestasi belajara, tes kemampuan pemecahan masalah, dan angket sikap percaya percaya diri siswa. Data hasil tes prestasi belajar (TPB) siswa dapat dilihat pada Tabel 9. Berdasarkan Tabel 9 diketahui pada posttest, ketuntasan belajar ditinjau dari prestasi belajar mencapai 97,5\%. Kriteria keefektifan terhadap prestasi belajar siswa terpenuhi berdasarkan hasil analisis data pada tes prestasi belajar yang menunjukkan persentase banyaknya siswa yang tuntas $\geq 80 \%$. Nilai rata-rata tes prestasi belajar pada posttest mencapai 82,6. Selain itu juga, terdapat peningkatan persentase ketuntasan belajar dan rata-rata nilai kelas berdasarkan hasil nilai pretest dan posttest. Sementara itu, data hasil tes kemampuan pemecahan masalah (TKPM) siswa dapat dilihat pada Tabel 10.

Tabel 10. Nilai Rata-rata dan Persentase Ketuntasan Belajar Berdasarkan TKPM Siswa

\begin{tabular}{ccccc}
\hline \multirow{2}{*}{ Jumlah Siswa } & \multicolumn{2}{c}{ Nilai rata-rata } & \multicolumn{2}{c}{ Ketuntasan } \\
\cline { 2 - 5 } & Pretest & Posttest & Pretest & Posttest \\
\hline 40 & 32,1 & 80 & $(0 \%)$ & $(95 \%)$ \\
\hline
\end{tabular}

Berdasarkan Tabel 10 diketahui pada posttest, ketuntasan belajar ditinjau dari kemampuan pemecahan masalah pada kelas uji coba mencapai 95\%. Kriteria keefektifan terhadap kemampuan pemecahan masalah terpenuhi berdasarkan hasil analisis data yang menunjukkan persentase banyaknya siswa tuntas $\geq 80 \%$. Nilai rata-rata tes kemampuan pemecahan masalah pada posttest mencapai 80. Selain itu, juga terdapat peningkatan persentase ketuntasan belajar dan rata-rata nilai kelas berdasarkan hasil nilai pretest dan posttest. Selanjutnya, data hasil angket sikap percaya diri siswa dapat dilihat pada Tabel 11.

Berdasarkan Tabel 11 diketahui ketuntasan belajar ditinjau dari angket sikap percaya diri siswa sesudah pembelajaran menunjukkan hasil bahwa sebanyak 4 siswa atau $10 \%$ memiliki sikap percaya diri yang sangat tinggi, sebanyak 30 siswa atau $75 \%$ memiliki sikap percaya diri tinggi, sebanyak 6 siswa atau $15 \%$ memiliki sikap percaya diri cukup. Berdasarkan data tersebut, ditinjau dari sikap percaya diri siswa, pembelajaran dikatakan efektif karena persentase banyaknya siswa memiliki sikap percaya diri dengan kategori minimal tinggi $\geq 80 \%$. Selain itu, juga terdapat peningkatan sikap positif dari hasil sebelumnya sebanyak $100 \%$.

Tabel 11. Persentase Pencapaian Hasil Belajar Berdasarkan Angket Sikap Percaya Diri Siswa

\begin{tabular}{lcc}
\hline \multirow{2}{*}{ Kategori Sikap } & \multicolumn{2}{c}{ Jumlah siswa (\%) } \\
\cline { 2 - 3 } & Sebelum & Sesudah \\
\hline Sangat tinggi & $3(7,5 \%)$ & $4(10 \%)$ \\
Tinggi & $25(62,5 \%)$ & $30(75 \%)$ \\
Cukup & $12(30 \%)$ & $6(15 \%)$ \\
Rendah & $0(0 \%)$ & $0(0 \%)$ \\
Sangat rendah & $0(0 \%)$ & $0(0 \%)$ \\
Kriteria minimal tinggi & $70 \%$ & $85 \%$ \\
\hline
\end{tabular}

Berdasarkan ketercapaian ketuntasan belajar dan peningkatan persentase ketuntasan yang diperoleh dalam penelitian ini menunjukkan bahwa penggunaan model pembelajaran problem-based learning (PBL) efektif digunakan dalam pembelajaran matematika. Hal ini dikarenakan dengan model PBL siswa diarahkan saling berbagi pengetahuan dengan teman untuk meningkatkan kemampuan berpikir dan memecahkan masalah. Hal ini sesuai dengan pendapat Arends \& Kilcher (2010, p.328) yang mengungkapkan bahwa PBL memberikan peluang kepada siswa untuk aktif dalam pembelajaran pendapat. Selain itu, Ertmer \& Simons (2006, p.51) bahkan mengungkapkan bahwa PBL tidak hanya meningkatkan kemampuan berpikir, tetapi juga membentuk siswa menjadi pemikir yang fleksibel.

Faktor lain yang menyebabkan ketercapaian tujuan dalam pengembangan perangkat pembelajaran dengan model problem-based learning PBL (prestasi belajar, kemampuan pemecahan masalah dan kepercayaan diri siswa) adalah adanya kegiatan pembelajaran yang bermakna, di mana siswa terlibat secara aktif dalam proses diskusi untuk mengidentifikasi masalah, memahami masalah, dan menyelesaikannya dengan memanfaatkan berbagai sumber pengetahuan dan sumber informasi sehingga pada akhirnya memperoleh pengetahuan baru. Kebermaknaan PBL ini sesuai dengan karakteristik dari PBL itu sendiri yang menghadirkan masalahmaslah dunia nyata dalam pembelajaran 
(Santrock, 2011, p.320; Ajai \& Imoko, 2015, p.47).

Hasil yang diperoleh dari pengembangan perangkat pembelajaran ini memiliki relevansi dengan beberapa penelitian yang melakukan eksperimen untuk menguji efektifitas PBL dalam pembelajaran matematika. Hasil penelitian tersebut antara lain menunjukkan bahwa implementasi problem-based learning dalam pembelajaran efektif dalam meningkatkan prestasi belajar siswa (Laili, 2016, p.31). Selain itu problem-based learning dalam penelitian yang dilakukan oleh (Angkotasan, 2013, p.99) juga efektif dalam meningkatkan kemampuan pemecahan masalah siswa. Sementara itu, berkaitan dengan kepercayaan diri siswa yang mengalami peningkatan juga relevan dengan hasil penelitian yang dilakukan oleh Suhendar \& Widjajanti (2016, p.99) yang mengungkapkan bahwa model-model pembelajaran yang menggunakan pendekatan konstruktivisme efektif dalam meningkatkan kepercayaan diri siswa.

Selain itu, beberapa penelitian yang mengembangkan model maupun perangkat pembelajaran mengunakan PBL juga memberikan hasil yang sejalan dengan temuan dalam penelitian ini. Hasil penelitian Rahmawati \& Suryanto (2014) menyimpulkan bahwa model pembelajaran matematika berbasis masalah yang dikembangkan efektif ditinjau dari prestasi belajar siswa penelitian Sulistyani \& Retnawati (2015) yang menyimpulkan bahwa perangkat pembelajaran bangun ruang di SMP dengan pendekatan problem-based learning efektif ditinjau dari pencapaian kompetensi dasar yang berkaitan dengan bangun ruang.

Berdasarkan uraian tersebut, dapat disimpulkan bahwa perangkat pembelajaran matematika SMP kelas VIII semester genap dengan model problem-based learning (PBL) berorientasi pada prestasi belajar, kemampuan pemecahan masalah, dan sikap percaya diri siswa pada kriteria valid, praktis dan efektif. Hal ini menunjukkan perangkat yang dikembangkan layak digunakan dalam pembelajaran dan dapat digunakan sebagai contoh pada pengembangan perangkat pembelajaran matematika.

\section{SIMPULAN}

Dari hasil penelitian dan pengembangan diperoleh kesimpulan bahwa hasil pengembangan merupakan perangkat pembelajaran matematika kelas VIII semester genap dengan model problem based learning (PBL). Hasil validasi menunjukkan bahwa perangkat pembelajaran yang dihasilkan memenuhi kriteria kevalidan dalam kategori sangat valid. Hasil penilaian kepraktisan menunjukkan bahwa perangkat pembelajaran yang dihasilkan memenuhi kriteria praktis baik ditinjau dari penilaian guru, penilaian siswa, dan keterlaksanaan kegiatan pembelajaran. Selain itu, ditinjau dari persentase ketuntasan prestasi belajar sebesar 97,5\% dan peningkatan nilai rata-rata kelas, tercapainya persentase ketuntasan kemampuan pemecahan masalah sebesar $95 \%$ dan peningkatan nilai ratarata kelas, serta ketuntasan sikap percaya diri dengan kategori minimal tinggi sebesar 85, perangkat pembelajaran yang dihasilkan memenuhi kriteria keefektifan.

\section{DAFTAR PUSTAKA}

Ahmadi, 1. K., \& Amri, S. (2014). Pengembangan \& model pembelajaran tematik integratif. Jakarta: Prestasi Pustaka.

Ajai, J. T., \& Imoko, B. I. (2015). Gender differences in mathematics achievement and retention scores: A case of problembased learning method. International Journal of Research in Education and Science (IJRES), 1(1), 45-50.

Angkotasan, N. (2013). Model PBL dan cooperative learning tipe TAI ditinjau dari aspek kemampuan berpikir reflektif dan pemecahan masalah matematis. PYTHAGORAS: Jurnal Pendidikan Matematika, $\quad$ 8(1), 92-100. doi:http://dx.doi.org/10.21831/pg.v8i1.84 97

Arends, R. I. (2008). Belajar untuk mengajar. (Terjemahan Helly Prajitno Soetjipto dan Mulyantini Soetjipto). New York, NY: McGraw Hill Companies. (Buku asli diterbitkan tahun 2007).

Arends, R. I., \& Kilcher, A. (2010). Teaching for student learning becoming an accomplished teacher. New York, NY: Routledge.

Azmandian, A. (2010). Think yourself successful. New York, NY: McGraw-Hill Companies, Inc.

Brown, M. W. (2009). The teacher-tool relationship: theorizing the design and use of curriculum materials. Dalam Remillard, J. T., Eisenmann, B. A. h., \& Lloyd, G. M. 2009. Mathematics teachers at work connecting curriculum materials 
and classroom instruction. New York, NY: Routledge.

Collins III, J. W. \& O'Brien, N. P. (2003). The greenwood dictionary of education. London, UK: Greenwood Press.

Cretchley, P. C. (2008). Advancing research into affective in mathematics learning clarifying key factors, terminology and measurement. Proceedings of The $31^{\text {st }}$ Annual Conference of The Mathematics Education Research Group of Australasia, 147-153.

Depdiknas. (2008). Panduan pengembangan bahan ajar. Jakarta: Direktorat Jenderal Manajemen Pendidikan Dasar dan Menengah Depdiknas.

Eric, C. C. (2010). Mathematical modeling in problem-based learning setting. Diambil dari singteach.nie.edu.sg

Ertmer, P. A., \& Simons, K. D. (2006). Jumping the PBL implementation hurdle: supporting the efforts of $\mathrm{K}-12$ teachers. Interdisciplinary Journal of ProblemBased Learning, 1, 40-54.

Farhan, M., \& Retnawati, H. (2014). Keefektifan PBL dan IBL ditinjau dari prestasi belajar, kemampuan representasi matematis, dan motivasi belajar. Jurnal Riset Pendidikan Matematika, 1(2), 227240.

Goel, M., \& Aggarwal, P. (2012). A comparative study of self-confidence of single child and child with sibling. International Journal of Research in Social Science, 2(3). 89-98.

Hamdan. (2009). Hubungan antara kepercayaan diri dengan motivasi berprestasi pada siswa SMUN 1 Setu Bekasi. Diambil pada tanggal 12 Agustus 2016, dari www.gunadarma.ac.id/library/articles/gra duate/psychology/.../Artikel_10504066.pd

Hannula, M. S., Maijala, H., \& Pehkonen, E. (2004). Development of understanding and self confidence in mathematics; grades 5-8. Proceedings of The $28^{\text {th }}$ Conference of The International Group For The Psychology of Mathematics Education, 3, 17-24.

Haylock, D., \& Thangata, F. (2007). Key concept in teaching primary mathematics. SG: Sage Publication.
Karatas, I., \& Baki, A. (2013). The effect of learning environments based on problem solving on students' achievements of problem solving. International Electronic Journal of Elementary Education, 5(3), 249-268.

Krulik, S., \& Rudnick, J. A. (1995). The new sourcebook for teaching reasoning and problem solving in elementary school. Needham Heights, MA: Allyn \& Bacon.

Laili, H. (2016). Keefektifan pembelajaran dengan pendekatan CTL dan PBL ditinjau dari motivasi dan prestasi belajar matematika. PYTHAGORAS: Jurnal Pendidikan Matematika, 11(1), 25-34. doi:http://dx.doi.org/10.21831/pg.v11i1.9 679

Liza, A. N., Karomiah. W., Abdullah. W., \& Yunita, A. (2011). Would problem-based learning affect student's generic competencies?. African Journal of Education and Technology, 1(3), 1-14.

Magsino, R. M. (2014). Enhancing higher order thinking skills in marine biology class through problem-based learning. Asia Pacific Journal of Multidisciplinary Research, 2(5), 1-6.

McArdle, G. (2010). Instructional design for action learning. New York: NY: Amacom.

Mendikbud. (2013). Peraturan Menteri Pendidikan dan Kebudayaan Republik Indonesia Nomor 65, Tahun 2013, tentang Standar Proses Pendidikan Dasar dan Menengah.

National Council of Teachers of Mathematics NCTM. (2000). Principles and standards for school mathematics. Virginia, VA: Author.

Nitko, A. J., \& Brookhart S. M. (2011). Educational assessment of students $\left(6^{\text {th }}\right.$ $e d)$. Boston, MA: Pearson Education, Inc.

Pimta, S., Tayruakham, S., \& Nuangchalerm, P. (2009). Factor influencing mathematic problem solving ability of sixth grade students. Journal of Social Sciences, 5(4), 381-385.

Rahmawati, U., \& Suryanto, S. (2014). Pengembangan model pembelajaran matematika berbasis masalah untuk siswa SMP. Jurnal Riset Pendidikan Matematika, $\quad$ 1(1), 88-97. 
Pythagoras, 12 (1), 2017 - 86

Maria Trisna Sero Wondo

doi:http://dx.doi.org/10.21831/jrpm.v1i1 . 2667

Republik Indonesia. (2003). Undang-undang RI Nomor 20, Tahun 2003, tentang Sistem Pendidikan Nasional.

Retnawati, H. (2016). Hambatan guru matematika sekolah menengah pertama dalam menerapkan kurikulum baru. Jurnal Cakrawala Pendidikan, 3(3). doi:http://dx.doi.org/10.21831/cp.v3i3.76 94

Sabrun. (2010). Pengaruh model pembelajaran problem-based learning (PBL) dalam meningkatkan kemampuan pemecahan masalah matematika siswa MTs NW Narmada ditinjau dari segi gender. Tesis,tidak dipublikasikan. Universitas Negeri Yogyakarta.

Santrock, J. W. (2011). Educational psychology $\left(5^{\text {th }}\right.$ ed $)$. New York, NY: McGraw-Hill Companies Inc.

Sastrawati, E., Rusdi, M., \& Syamsurizal. (2011). Problem based learning, stategi, metakognisi, dan keterampilan berpikir tingkat tinggi siswa. Tecno Pedagogi, 1, $1-14$.
Suhendar, U., \& Widjajanti, D. (2016). Komparasi keefektifan saintifik dan PMRI ditinjau dari prestasi, minat, dan percaya diri siswa kelas VII. PYTHAGORAS: Jurnal Pendidikan Matematika, 11(1), 91-101. doi:http://dx.doi.org/10.21831/pg.v11i1.9 674

Sulistyani, N., \& Retnawati, H. (2015). Pengembangan perangkat pembelajaran bangun ruang di SMP dengan pendekatan problem-based learning. Jurnal Riset Pendidikan Matematika, 2(2), 197 - 210. doi:http://dx.doi.org/10.21831/jrpm.v2i2. 7334

Sumarmo, U., \& Nishitani, I. (2010). High level mathematical thinking: experiments with high school and under graduate students using various approach and strategies. Diambil dari https://goo.gl/5illwi.

Sungur, S., \& Tekkaya, C. (2006). Effects of problem based learning and traditional instruction on self-regulated learning. The journal of educational research, 99, 307317.

Trianto. (2012). Model pembelajaran terpadu: Konsep, strategi, dan implementasi dalam KTSP. Jakarta: Prestasi Pustaka Publisher. 